\title{
Sexual Harassment and Abuse in Sports: In the Context of Turkey Sample Determination of Risk Factors in Relationship of Coaches and Female Athletes
}

\author{
Mustafa Serdar Terekli ${ }^{1}$, Halil Orbay Çobanoğlu ${ }^{2}$ \\ ${ }^{1}$ Department of Sports Management, Faculty of Sports Sciences, Eskişehir Technical University, Eskişehir, Turkey \\ ${ }^{2}$ Muzaffer Çil Anatolian High School, Ministry of National Education, Eskişehir, Turkey \\ Correspondence: Halil Orbay Çobanoğlu, Muzaffer Çil Anatolian High School, Ministry of National Education, Eskişehir, \\ Turkey. Tel: +90-545-223-20-08. E-mail: orbay_79@hotmail.com
}

\author{
Received: July 20, $2018 \quad$ Accepted: September 10, $2018 \quad$ Online Published: September 12, 2018 \\ doi:10.11114/jets.v6i10.3616 URL: https://doi.org/10.11114/jets.v6i10.3616
}

\begin{abstract}
Today, sexual harassment is common in all areas of daily life. Numerous scientific researchers have been conducted since the rate of sexual harassment has increased day by day. Nowadays, the increase of sexual abuse and harassment in almost every area of organizational structure and field is creating a serious threat, and it has forced many managers and academics to come together. In addition to the many organizations that have experienced sexual harassment, since many years sexual harassment and abuse have increased in sport fields and in different sport branches. What is the characteristic that makes sports field an area open to sexual abuse and that differs from other social areas? The first answer that comes to mind is transparency. Sports is seen as a transparent area due to the fact that it is independent of other areas of life. That is, the sport field is not operating as a different area which emphasizes only physical performance or ability regarded as a different field. Sexual harassment and abuse are not events that happen on their own in the sport. While harassment and abuse events in many areas of society are difficult to reveal, harassment and abuse events in sports are very visible. However, this visibility is only within the community. When you ask almost every sector working in the sports field, it seems that there is a story of harassment that they have lived or heard about in the past. The aim of this study is to offer suggestions to the athletes, their families and coaches for the prevention of sexual harassment and abuse in sport in order to eliminate the negative impact on athletes who have experienced and encountered sexual harassment and abuse in Turkey.
\end{abstract}

Keywords: sexual harassment, female athlete, coach education, sport, sexual abuse

\section{Introduction}

With the development of Modern Olympics, there has been an increase in the number of female athletes. For this reason, the visibility of women athletes, trainers and supporters in today's sports world is very different from their previous state for a century (Temel \& Güllü, 2016). Female athletes, who were identified only for some branches in the early years of the Olympics, are now participating in many branches, including the wrestling which is our ancestor sport. In addition to many organizations that have experienced sexual harassment, since many years sexual harassment and abuse have increased in sport fields and in different sport branches (Yücel et al., 2014).

The concept of sexual harassment was first described in the book "Sexual Harassment of Working Women" by law professor Catherine Mac Kinnon and she defines "sexual harassment" as the "unwanted imposition of sexual requirements in the context of a relationship of unequal power." Mac Kinnon pioneered the discussion of sexual harassment, and after that date the debate focused on the dimensions and definition of sexual harassment (Mimaroğlu \& Özgen, 2008).

Sexual harassment can take many different forms - it can be obvious or indirect, physical or verbal, repeated or one-off and perpetrated by males and females against people of the same or opposite sex. Sexual harassment may include (Australian Human Rights Commission, 2009):

- $\quad$ Staring or leering

- Unnecessary familiarity, such as deliberately brushing up against you or unwelcome touching 
- Suggestive comments or jokes

- Insults or taunts of a sexual nature

- Intrusive questions or statements about your private life

- Displaying posters, magazines or screen savers of a sexual nature

- Sending sexually explicit emails or text messages

- Inappropriate advances on social networking sites

- Accessing sexually explicit internet sites

- Requests for sex or repeated unwanted requests to go out on dates

- Behavior that may also be considered to be an offence under criminal law, such as physical assault, indecent exposure, sexual assault, stalking or obscene communications.

Sexual abuse can be defined as a sexual relationship with persons of any age, without their consent, in an aggressive and threatening manner, against the will of the victim. Sexual abuse involves any sexual act in which consent is not shown.

The concept of sexual abuse refers to the abuse of individuals who are not consent or who are not consent for reasons such as a small age or mental illness, and the use of physical force, deceit, deceit or threat to the sexual orientation of others, even if they do not want to be targeted. Of each gender, people from all social strata and professional groups can be victims of sexual abuse and exploitation. In addition, it can be said that women and children are more exposed to sexual exploitation in general (Yıldız, 2009).

There is still little information about the dynamics of sexual exploitation in sports. Although there are many popular publications on the subject, sexual abuse in sports is still the least researched issue. Finkelhor's four factor theory of sexual abuse, generated and widely used outside sport, has previously been cited by Brackenridge as relevant to the sport context but has not been clearly integrated into the analysis of risk factors. According to this theory, sexual abuse takes place only if four, sequentially linked factors coincide: First, the motivation of the potential abuser to abuse sexually; secondly, the overcoming of the potential abuser's internal inhibitions; thirdly, the overcoming of external inhibitors and finally, the overcoming of the child's resistance. This model of finkelhor was welcomed as an individual antidote in sociology and in many areas. Brackenridge (1997) has pointed out that there is a need for a contingency theory of sexual abuse in sport that accounts for not just the athlete, the coach and the sport but which also explains personal and situational interaction effects (Cense \& Brackenridge, 2001).

The only development-related, theoretical proposal put forward so far in the context of sport has been by Brackenridge and Kirby (1997). They suggest that there is a higher risk of sexual abuse to an athlete at the 'stage of imminent achievement' (SIA), just prior to elite (international) level, especially where this coincides with puberty. Further empirical work is required to test whether this proposition has validity. If it does, then the SIA will be useful for predicting risk and focussing resources for the prevention of abuse. It may also help researchers to understand the ontogeny of sexual abuse experiences in sport (Brackenridge \& Kirby, 1997).

\section{Sexual Harassment and Abuse Research and Examples in Turkey}

Sexual abuse occurs at all levels of sports, while the elite seen as higher in sports. The risks of sexual abuse can also be associated with more risks, especially in adolescence, in sports that are heavily screened for talent. In contrast to some unrealistic expressions in sports, there is no evidence that wearing, touching, or sexual abuse is specific to a particular type of sport. Sexual abuse occurs in all sports, individual and team Sports. For this reason, sports type is not considered as a risk factor for the occurrence of sexual abuse. There are some situations where there is a high risk of sexual abuse in sports. These are places where sexual harassment can occur. The dressing room, the home of the trainer, the coach's vehicle, that is, the areas that are free of other athletes (Marks, Mountjoy \& Marcus, 2011).

An in-depth observation of the development of a coach-athlete relationship, how it can lead to sexual abuse, can help to prevent this abuse and improve its early identification. The development of this relationship can be considered as the 'preparation' process for sexual harassment. This process is a very important precursor to sexual approaches and involves building trust, gradually pushing back the boundaries of acceptable behavior, and gradually violating more personal space through verbal familiarity, emotional blackmail and physical touch (Brackenridge, 1997).

Most of the time, between coaches and athletes, there are early signs of abuse of power, which is important for abuse (Marks, Mountjoy \& Marcus, 2011); These are:

- Targeting the victim.

- Establishing trust and friendship

- Developing control and loyalty.

- Creating and securing privacy.

In the beginning, the coach identifies the victim, finds a potentially vulnerable athlete and seems to be (pretends to be) a 
friend with this athlete. These athletes are often vulnerable because they are more separate than their teammates, because their relationships with their parents are weak and / or because they have a few friends (Brackenridge, 1997).

The coach establishes trust and friendship, and through this friendship, the coach establishes a more reliable relationship by giving the athlete awards or presents and making her / him feel special. With these awards, the coach can then say, "you have to do this (sexual activity), because (I gave you this award)..." The coaches can then develop more control and loyalty by refusing to give athlete access to important people, friends and supporters. This may involve restricting access to the athlete's parents as a way of controlling the athlete's and her / his parents. For example, in qualitative interviews with athletes who experience sexual abuse, athletes said that developing a strong sense of attachment to the coach led to more cooperation with the coaches' sexual behavior. After the abuse has started, the coach can continue to create and secure confidentiality by providing the results of sexual restraints. Coach can use expressions like "you owe me" or "our little secret."

Sexual abuse in Turkey is considered a crime. In the Republic of Turkey Turkish Criminal Code sexual abuse, sexual relations with minors is regulated by legal provisions relating to sexual harassment and crime. In the present practice, these laws are not enough, the cases of sexual harassment committed against women and children have increased and the punishment of the criminals have not relieved the conscience of society. Because in our country 2017 is the year of shame in terms of crimes committed against women and children. According to the data obtained in 2017, 409 women were murdered, 387 children were sexually abused and 332 women were sexually abused. Only in December 45 women were killed by their relatives. These numbers are officially identified.

Fatih Terim, Turkey Football Director, in an interview on Child Abuse in infrastructure, said "as soon as I came on duty, I ordered the creation of a unit on this subject. When we started this practice, we saw that we were facing a much more difficult, bigger and deeper problem. More important than physical and emotional abuse, we found that there was a lot of sexual abuse. It comes to us with most complaints about coaches. Those who reach us are complaining about unfit abusers and asking for help. Sometimes, not only coaches of children, but even their brothers and uncles can be dangerous. We all have a duty to get them out of us" (Kuşçu, 2016).

In addition, in 2018, it was learned that there was a sexual abuse of the trainer's student in the Fencing Women's National Team. The father of a 15 year-old national fencer who had been abused by his coach for 3 years told by crying "My daughter told me by crying, and the only child abused by this pervert is not our daughter. Except for our daughter, three other young girls will tell their story. We've been prosecuting the coach. My child was threatened. He said, "it would be worst, if you told someone". "You hurt yourself, you hurt me". "I created you, you are nothing without me". First he gains their confidence, he puts pressure on them, then he does all kinds of devilishness and obnoxiousness. Our 15-year-old daughter is a national fencer. She has medals and international success. She's been very close lately. We thought it was because of puberty. She has been subjected to sexual abuse and harassment by her coach for three years. We also used the new learned expression" (T24, 2018).

National weightlifter Aylin Daşdelen said: "We have experienced so many ugly things. I was going to explain all this before, but I'm going to explain it now so that the Olympics don't fall apart. I started weightlifting in 1994 and the person who abused us was working as a coach. He said, " you're gonna have to put up with some things, and if you don't put up with them, you won't succeed." He abused many girls. One day he took me to the hotel saying he'd take me to the federation and tried to harass me. He even tried to kiss me. I said, "I would tell my dad." He slapped me and kicked me. I was 14 at the time. Esma can, weightlifter's friend, committed suicide by taking pills in his room in 1998 because of the abuse." Sibel Şimşek, Aylin Daşdelen and (Ş.Ş.), another female athlete who does not want her name to be revealed, claimed sexual harassment about their coaches. Ş.Ş., weightlifter with a complaint from her coaches, said in her petition "I tried to commit suicide three times" (Hürriyet Spor, 2004).

Volleyball trainer, raped a 9 years old girl athlete, for 3 years and recorded images of disgusting moments. The coach was arrested and sentenced to the most severe. But when he was in prison, the photos and videos of the athlete presented as evidence to the court began to spread on the Internet (Arman, 2018).

F.C., assistant professor of Physical Education and Sports at Marmara University, attempted to rape S.D. who was 16-year-old athlete coaching by F.C.F.C. threw drugs in his student's drink and tried to rape her. She noticed the situation and quickly fled the house (Haber3, 2008).

Coach M.K., age 56, who came to the handball tournament in Alanya from Samsun, was charged with sexual abuse at 16-year-old S.B., and was sentenced to 15 years of imprisonment in the 2 nd heavy penal court in Alanya. Ali, who was a sexual exploiter by calling her teammate student S.B. to his room and removing her with the pretext of checking clothes, was delivered to the Alanya L. Type Closed Prison (Al, 2018). 
The former materialist of the basketball team in Aliaga, Izmir, who has three children, was arrested on charges of sexual harassment of 12-year-old children (İHA, 2010). In Muğla, M.A., a sports club materialist, was arrested on charges of harassing a male football player in infrastructure, the 12-year-old, by hand and verbally (Akgün, 2018).

He was arrested on charges of sexual abuse by the general captain of the Etilerspor club, known for his reputation for creating stars from young talents. The incident occurred with the application of their families to the police department. Families have reported that the general captain of the club has found out that he has sexually abused his children and that they are complaining. It turned out that many of the victims were under 18 years of age (Radikal, 2013).

In Izmir, the suspect, who was arrested on charges of sexual harassment of children around school by introducing him as a sports teacher, was referred to the courthouse (Memleket, 2017).

Gündüz et al. (2002) in their study conducted on elite women athletes, $200(56.2 \%)$ of the 356 people in different sports were subjected to sexual harassment by spectators, coaches, managers and other athletes in the same or different teams. Regarding the area where sexual harassment is encountered, $45.5 \%$ (162) of the athletes expressed 'the gym' as the place of the sexual harassment, while 104 athletes $(29.2 \%)$ accepted the relationship between the wearing in the sport and the harassment. Female athletes with a maximum of $40 \%$ of the audience then $33.1 \%$ of male teammates and $24.8 \%$ of their coaches stated that they were sexually harassed in various ways (Gündüz et al., 2002).

A study, researched in 11 Physical Education and Sports schools affiliated to eight public universities in Marmara, Aegean, Mediterranean and Central Anatolia, in order to determine how female students are exposed to sexual abuse by their instructors, how they are exposed to it (variety) and ways of coping with sexual harassment, it is stated that $25.5 \%$ of the female students at least once sexually harassed by faculty members. It has been determined that forms of harassment offer disturbing views of unwanted sexual interest, obscene jokes, and persistent dismissal. It is found that the majority of the students did not complain about for "social relations being harmed" and "fearing that they would be blamed" and $2 \%$ of the students complained (Yıldiz, 2009).

In 2009, a survey of 20 questions was carried out in order to make a preliminary study on the measurement of sexual harassment to 200 athletes active in the master's study conducted by Yildiz. In the study the question of 'Sports Clothes have an effect that can lead to sexual abuse? "61.5\% (115 athlete) of all athletes answered 'No"'. Similar results were found in another study conducted by Fasting et al. (2003). In this study in Norway, sportswear of athletes subjected to sexual harassment and abuse are classified on the basis of covering the body and divided into degrees such as less, medium and very. In the study, it was determined that there was no correlation between sexual abuse and sportswear (Fasting et al., 2003). "When did you encounter sexual abuse?" in response to the question, most of time that athletes are exposed to sexual harassment has been determined to respond after training. Women who have been sexually harassed athletes 32 with $50 \%$ women said that "sportive performance had changed." 30 of 32 athletes said that "performance decreased" 2 of 32 athletes said "increased". The factors that caused this increase in performance athletes after sexual harassment and abuse have been investigated, and a woman who is an athlete that exposed to sexual abuse said "When we didn't perform well, the punishment was to sit on the coach's lap. We had a run at the training field, and we had to sit on the coach's lap, which is the end of the run, so everyone would run to death" (Yıldiz, 2009).

As shown in the studies and examples above, sexual abuse and harassment are always seen in sports, but the fact that it is identified as a crime is only revealed through research that the victim has the courage to do.

The athlete is the individual who is responsible for delivering his / her performance to the highest level of performance only physically and mentally. The coach is the one who makes all these positive situations. Another of the most prominent features of the sports community is that the hierarchy of coaches and athletes, established in the direction of the goal of achieving the best rating of the athlete, is a power relation that can not be broken easily. The reason why sexual harassment often occurs in the sports community should be sought in relation to the mentioned power. The power disparity and dependency relationship between the coach and the athlete are the conditions that prepare the sexual abuse ground. In many scientific investigations of sexual harassment in sports, risk factors that may cause sexual abuse include showing the coach as a family grown up and a father and entrusting the children of their families to the coaching (Koca, 2008). For example, the romantic / sexual relationship between the coach and the athlete is considered to be the abuse of power and professional status as the coach has a professional responsibility on the athlete.

\section{Sexual Harassment and Abuse in Sports}

The most significant difference between the victim and the abuser in sports is the age difference. In sports areas, the coach is usually used by young people in early ages to help them in sports training. It should not be forgotten that the coach has rewarding power, compelling power, legitimate power, expertise and charismatic power. What is important is whether these powers are used for abuse. If one or more of these forces are addictive to the athlete, the abuse of the power is potentially open. If the coach is a male, the young athlete is a woman, the intensity and frequency of use of the 
coach may increase. Most of the abusers are males in sports. Male sexual abuse and discrimination can often constitute violent behavior patterns such as sexual partners, sexual abuse and child abuse. Abusives, in the field of sports, are known by children. However, the closer the relationship, the greater the secret. Figure 1 below shows that sexual abuse increases compared to athletic development levels in sports (Brackenridge \& Kirby, 1997: 18).

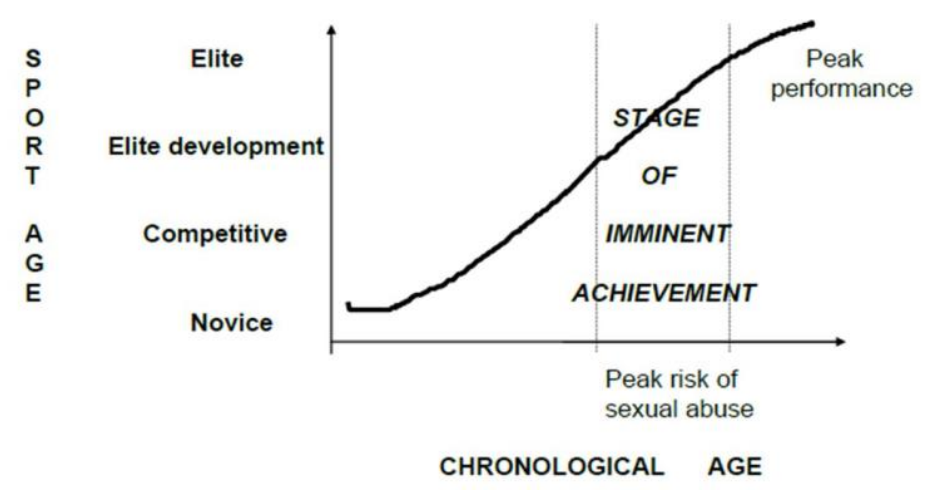

Figure 1. Risk of Sexual Abuse: Chronological Age by Sport Age

In studies that performance level in sports and prevalence of sexual harassment found higher sexual abuse in elite female athletes in Norway. In some study of sexual harassment and abuse in Australian sport, compared prevalence data between elite and club-level athletes: the elite group reported significantly higher rates of sexual abuse in sport than did the club group. But as with other studies of sexual harassment in sport data were not collected from exercisers. Accordingly, relatively little is known about the comparative sexual harassment experiences of non-elite athletes and exercisers (Fasting, Brackenridge \& Knorre, 2010).

All athletes have the right to 'safe sport', defined as a sporting environment free of all forms of violence against respectful, just and sportsmen. Any harassment or abuse can violate human rights and constitute a criminal offense. The cultural context of harassment and abuse derives from discrimination based on power differences between various social and personal factors. Sexual harassment and abuse in sports are caused by abuse of power relations.

\section{Physical and Psychological Consequences of Sexual Harassment and Abuse in Sports}

As the psychological consequences of sexual abuse and exploitation are less observable in sports, the detection of these concerns requires awareness that such problems occur in the sporting world and that they are sharply adapted to the possible consequences of harassment. Table 1 summarizes the various psychological consequences that can occur as a result of sexual harassment and abuse and in a similar manner outside of sport. Psychological manifestations include weight loss / gain, bed wetting, fatigue / decreased energy gain, physical damaging behaviors, and sexually transmitted infections. There may also be outward statements of sexual harassment and abuse of the sports. Risky or self-harming activities can also be observed by the doctor. There may be other social or behavioral problems. Damage to others (such as harming pets, peers, school friends or neighbors and family members) can be counted. Persons experiencing harassment can also identify weaknesses in interpersonal relationships and difficulties in trust. 
Table 1. Psychological Consequences of Sexual Abuse and Harassment in Sports

\begin{tabular}{|c|c|}
\hline & Symptoms \\
\hline Physical Psychological Results & $\begin{array}{c}\text { Weight loss / weight gain } \\
\text { Bed Wetting } \\
\text { Fatigue / energy shortage } \\
\text { Behavior causing physical damage to action } \\
\text { Sexually transmitted infections }\end{array}$ \\
\hline Self-harm behaviors & $\begin{array}{c}\text { Extreme diet } \\
\text { Cut or break the skin } \\
\text { Hair pulling }\end{array}$ \\
\hline Damage to others & $\begin{array}{c}\text { Pet } \\
\text { Bullying to peers } \\
\text { Harm to schoolmates or neighbors } \\
\text { Harm to the family }\end{array}$ \\
\hline Suicide/murder & $\begin{array}{l}\text { Thought of suicide } \\
\text { Suicide attempt } \\
\text { Completed suicide } \\
\text { Thought of murder } \\
\text { Homicide attempt } \\
\text { Completed murder }\end{array}$ \\
\hline Clinical depression & $\begin{array}{c}\text { Mood (sad, angry) } \\
\text { Decreased tastiness } \\
\text { Appetite change } \\
\text { Change in sleeping habits } \\
\text { Decreased concentration } \\
\text { Guilt } \\
\text { Hopelessness } \\
\text { Despair } \\
\text { Libido loss } \\
\text { Energy Loss } \\
\text { Suicidal thought and / or attempt }\end{array}$ \\
\hline Anxiety and anxiety disorders & $\begin{array}{c}\text { Physical stress } \\
\text { Nightmares } \\
\text { Obsessive-compulsive behavior / disorder } \\
\text { Acute and chronic posttraumatic stress disorder } \\
\text { Hyper awake }\end{array}$ \\
\hline
\end{tabular}

Source: Marks, Mountjoy \& Marcus, 2011: 3.

Psychological harassment and abuse can impair long-term physical and psychological health that affects personal and social development. There may be damage to a number of related problems such as self-harm, suicide, somatic diseases, harmful disorders and self-esteem. Athletes' feelings of anxiety and depression, low self-esteem, poor body image can occur and that the sport dropped from the resulting (self-report) may vary. Depending on sexual and physical abuse; childhood psychological abuse, after a long period of trauma among athletes, can lead to many psychological problems such as sad, scary, embarrassing, fainting and forgetfulness.

Numerous scientific studies have shown that sexual abuse leads to increased risk of mental health concerns. For example, people who experience sexual harassment often have clinical depression and higher suicidal ideation and suicide attempts. In addition to depression, people show increased anxiety and anxiety disorders after harassment and abuse. Sexual abuse can also have negative effects on self-esteem and body image. Similarly, athletes may be engaged in substance abuse as a result of sexual harassment and abuse.

Physical injuries, deaths, menstrual delays, other organic health problems, mental illnesses, and social, emotional, and cognitive disorders can be seen among potentially devastating effects of physical violence caused by sexual harassment and abuse in sports. In particular, physical outcomes can produce very significant negative consequences for children or adolescent athletes due to the growth and maturation processes associated with their vital stages.

According to other areas, sexual abuse and abuse in sports can be detected more easily because the physical results are more visible than the psychological consequences. An athlete who is abuse victim in sports may apply to the sports physician for various medical worries. Physical reactions include headache, numbness, sleep disturbances, weight fluctuations, and worse general health satisfaction. In a study conducted in Ireland, it was found that people who have 
been sexually abused have worse health outcomes in some areas. These are; general health, digestive health, gynecological or reproductive health, pain, weakness of circulation and obesity. There is also another danger seen in the sports; alcohol poisoning, and even extreme physical consequences such as death.

\section{Conclusion}

Sexual harassment and abuse incidents require social sensitivity. Every individual and society should be able to draw conclusions from these incidents and should feel responsible. By taking the necessary precautions required to be taken in order to prevent such incidents and carrying out the necessary studies, each segment of the society should raise their awareness (Yücel et al., 2014). Regarding sexual harassment and abuse, both the athletes and the parents and coaches must be conscious. Because the athletes and the families do not know what sexual abuse and abuse mean. They also have no idea when the harassment began and how it continued. Most of the coaches that they pass by saying "close attention" are actually harassing. It is especially important that families understand that sports children can be exposed to great emotions such as shame, guilt and fear. It is very important to accept the courage to speak about this abuse and to tell them that it is not their fault for their children to return to the athlete. Families have the duty to report abuse of power to certain authorities. Early diagnosis for children who are exposed to such behavior may play an important role in preventing such events. Neglect to ignore abuse of power or to stop abuse serves to increase psychological problems arising from harassment and abuse. Physical contact cannot be proven in sports. Sexual harassment can take a long time to be reported. An athlete can find the courage to report the abuse after she / he gets rid of the coach's influence. Coaches who are effective in federations can have a say against managers, and managers can ignore allegations of harassment in their power to prevent their names from being compromised by bad events.

Most of the time, there are early signs of harassment and abuse among coaches and athletes. The rules of conduct of coaches in sport should always have limits. In general, to prevent harassment and abuse in sports, attention should be paid to the details given below, even if they are not clearly stated in the code of conduct.

- Never be alone with an athlete

- Never share a hotel room

- Do not continue to deal with your athlete after training

- At whatever level your athletes are, you should always be at a professional level

- The power use of the coach in sports must always be positive for the athlete and you should equally behave everyone.

- Families should analyze and observe their children well. Speaking absolutely with your child that you see behavioral disorders.

\section{References}

Akgün, C. (2018, April 6). Sexual harassment of a football player at the age of 12. Retrieved from http://www.hurriyet.com.tr/gundem/12-yasindaki-futbolcuya-cinsel-taciz-40796848

Al, M. (2018, June 3). Punishment to coach for sexual abuse. Retrieved from https://www.sabah.com.tr/akdeniz/2018/06/03/antrenore-cinsel-istismar-cezasi

Arman, A. (2018, July 15). Her coach raped to child 9 years old. Retrieved from https://www.cnnturk.com/turkiye/antrenoru-9-yasindaki-cocuga-tecavuz-etti

Australian Human Rights Commission (2009). Identifying sexual harassment. Retrieved from https://www.humanrights.gov.au/our-work/sex-discrimination/guides/sexual-harassment

Brackenridge, C. H. (1997). "He owned me basically..." Women's experience of sexual abuse in sport. Int. Rev. Social. Sport, 32, 115-130. https://doi.org/10.1177/101269097032002001

Brackenridge, C. H., \& Kirby, S. (1997). Playing safe? Assessing the risk of sexual abuse to young elite athletes, International Review for the Sociology of Sport, 32(4), 407-418. https://doi.org/10.1177/101269097032004005

Cense, M., \& Brackenridge, C. (2001). Temporal and developmental risk factors for sexual harassment and abuse in sport. European Physical Education Review, 7(1), 61-79. https://doi.org/10.1177/1356336X010071006

Fasting, K., Brackenridge, C. H., \& Knorre, R. (2010, April). Performance Level and Sexual Harassment Prevalence among Female Athletes in the Czech Republic. Human Kinetics Journal, 19(1), 26-32. https://doi.org/10.1123/wspaj.19.1.26

Fasting, K., Brackenridge, C. H., \& Sundgot, B. J. (2003). Experiences of sexual harassment and abuse among Norwegian elite female athletes and non-athletes, Research Quarterly for Exercise and Sport, 74(1), 84-97. https://doi.org/10.1080/02701367.2003.10609067 
Gündüz, N., Koz, M., Fedai, T., Sunay, H., \& Ersöz, G. (2002). The investigation of sexual harassment faced by the elite female athletes in different sports fields in Turkey. Journal of Sports Research, 6(1), 95-108.

Haber 3, (2008, May 9). Nuri Alço Trapper to 16 age student. Retrieved from https://www.haber3.com/guncel/16-yasindaki-ogrenciye-nuri-alco-gibi-tuzak-haberi-332265

Hürriyet Spor (2004, September 9). Harassment shock in weightlifting team. Retrieved from http://www.hurriyet.com.tr/halter-takiminda-taciz-soku-256235

İHA, (2010, June 26). Abuser was arrested in Izmir. Retrieved from http://www.iha.com.tr/haber-izmirde-tacizci-tutuklandi-126970/

Koca, C. (2008). Sexual Harassment in Sports Field. Retrieved from https://bianet.org/biamag/toplumsal-cinsiyet/110161-spor-camiasinda-cinsel-taciz

Kuşçu, F. (2016, November 30). Fatih Terim has declared war on harassment. Retrieved from http://www.haberturk.com/spor/futbol/haber/1330490-fatih-terim-tacize-savas-acti

Marks, S., Mountjoy, M., \& Marcus, M. (2011). Sexual harassment and abuse in sports: The role of the team doctor. British Journal of Sport Medicine, 46(13), 905-908. https://doi.org/10.1136/bjsports-2011-090345

Memleket, (2017, October 12). Sexual Harassment Allegations in Izmir. Retrieved from http://www.memleket.com.tr/izmirdeki-cinsel-taciz-iddiasi-1234005h.htm

Mimaroğlu, H., \& Özgen, H. (2008) Power Inequalities and Sexual Harassment in Organizations. Çukurova University Journal of Social Sciences, 17(1), 321-334.

Radikal, (2013, July 21). Football coach arrested for harassment of students. Retrieved from http://www.radikal.com.tr/spor/futbol-kocu-ogrencilerine-tacizden-tutuklandi-1142710/

T24 (2018). Harassment in Female National Fencing Team. Retrieved from http://t24.com.tr/haber/eskrim-bayan-milli-takiminda-cinsel-taciz,623170

Temel, C., \& Güllü, M. (2016). Social gender in the pictures drawn by students about physical education class. Educational Research and Reviews, 11(8), 530-536. https://doi.org/10.5897/ERR2015.2603

Yıldız, Ö. S. (2009). A Pilot Study on the Identification of Sexual Harassment and Abuse in Sports, Istanbul University, Institute of Forensic Medicine, Department of Social Sciences, Master Thesis, İstanbul.

Yücel, A. S., Korkmaz, M., Karataş, Ö., Hergüner, G., Yaman, Ç., \& Çatıkkaş, F. (2014). Determination of Sexual Harassment and Abuse Women Athletes Face in Sports: A case study. South Asian Journal of Experimental Biology, 4(3), 133-140.

\section{Copyrights}

Copyright for this article is retained by the author(s), with first publication rights granted to the journal.

This is an open-access article distributed under the terms and conditions of the Creative Commons Attribution license which permits unrestricted use, distribution, and reproduction in any medium, provided the original work is properly cited. 